http://dx.doi.org/10.11646/phytotaxa.170.4.2

\title{
Gomphonema svalbardense sp. nov., a new freshwater diatom species (Bacillariophyta) from the Arctic Region
}

\author{
EVELINE PINSEEL ${ }^{1,2}$, KATEŘINA KOPALOVÁ ${ }^{3,4} \&$ BART VAN DE VIJVER $^{1,2^{*}}$ \\ ${ }^{1}$ Botanic Garden Meise, Department of Bryophyta \& Thallophyta, Nieuwelaan 38, 1860 Belgium (*vandevijver@br.fgov.be, \\ corresponding author) \\ ${ }^{2}$ University of Antwerp, Department of Biology, ECOBE, Universiteitsplein 1, 2610 Wilrijk, Belgium \\ ${ }^{3}$ Centre for Polar Ecology (CPE), Faculty of Science, University of South Bohemia, Branisovska 31, 37005 Ceske Budejovice, Czech \\ Republic \\ ${ }^{4}$ Charles University in Prague, Faculty of Science, Department of Ecology, Viničná 7, 12844 Prague 2, Czech Republic
}

\begin{abstract}
During a survey of freshwater diatoms from lakes in the region of Petuniabukta on Spitsbergen (Svalbard Archipelago) a new Gomphonema species, G. svalbardense sp. nov., has been recorded. The new taxon was previously cited in the literature as G. angustatum var. undulatum but this identification proved to be erroneous. Detailed morphology description of G. svalbardense based on light and scanning electron microscopy is presented in this paper and the morphological features of the taxon have been compared with similar species. Gomphonema svalbardense is characterized by its typical linear, almost naviculoid outline with undulating margins, with clearly inflated central part, asymmetric central area, lateral raphe with simple straight proximal endings and the weakly radiate striae. History, ecology and biogeography of the species, mainly based on literature data, have been included.
\end{abstract}

Key words: Svalbard, Arctic Region, Gomphonema, diatoms, taxonomy, morphology, new species

\section{Introduction}

In the middle of the twentieth century, the diatom flora of the Arctic Svalbard Archipelago $\left(74^{\circ}-81^{\circ} \mathrm{N}, 10^{\circ}-35^{\circ} \mathrm{E}\right)$ was the focus of several large morphological and taxonomic studies, published by among others Hustedt (1937), Krasske (1938) and Foged (1964), the latter listing more than 572 taxa in 207 samples. During more recent years, diatom studies on Svalbard were restricted to a few sparse floristic and (paleo-)ecological accounts (e.g., PicińskaFałtynowicz 1988, Beyens 1989, Van de Vijver et al. 1999, Guilizzoni et al. 2006, Luoto et al. 2011) and only a few new taxa were described from the archipelago. Van de Vijver et al. (2004) described three new Stauroneis taxa from Svalbard in their revision of this genus in the Arctic and Antarctic Regions.

Since 2011 the interest in diatom research on Svalbard has revived with the Czech education program of polar ecology undertaken by the Centrum for Polar Ecology (University of South Bohemia). During the regular field expeditions, several lakes in the surroundings of the Petuniabukta fjord area have been studied (Reports of Czech research activities in Petuniabukta, http://polar.prf.jcu.cz/docs_cz.htm). The Petuniabukta fjord area is located in the northern part of Billefjorden, the inner branch of Isfjorden in the central part of Spitsbergen, the main island of the Svalbard Archipelago. The area is situated in the maritime High Arctic climate zone, with a mean annual temperature of about $-7.5^{\circ} \mathrm{C}$ and low precipitation rates of about $200 \mathrm{~mm}$ a year, mainly in the form of snow (Rachlewicz et al. 2007, Komárek et al. 2012, Láska et al. 2012). The geology of the study area is strongly correlated to the north-south facing Billefjorden Fault zone which resulted in a complex of different rock formations belonging to four structural entities differing in age and origin (Dallmann et al. 1999, Szczuciński \& Rachlewicz 2007). The entire fjord is surrounded by steep mountains ranging between 265 and $935 \mathrm{~m}$ a. s. 1. (Komárek et al. 2012). During the early Holocene, the entire area rose due to glacioisostatical uplift which resulted in the development of several good-preserved marine terraces (Szczuciński \& Rachlewicz 2007). About ten glaciers, of which the tide-water glacier Nordenskiöld is the biggest, are located in the area. Since the beginning of the $20^{\text {th }}$ century, the glaciers are retreating with speeds ranging from a few meters to 50 meters a year (Szczuciński 
or s-shaped with or without central flaps [e.g., G. acuminatum Ehrenberg (1832: 88)-complex and the G. truncatum Ehrenberg (1832:88)-complex] (Reichardt 1999, 2001). Occasionally species show depressed areolae such as in $G$. vibrioides (Reichardt 1991: 524) or G. latipes Reichardt (2001: 196), but never as deep as in G. svalbardense where the areolae are small rounded poroids each positioned eccentrically at the bottom of a deep, irregularly shaped depression. Reichardt (1999) showed one picture of G. lapponicum (Plate 46, fig. 10) where rounded areolae are visible at the bottom of shallow, rounded depressions but this structure is entirely different from the areolae in $G$. svalbardense. The internal opening of the isolated pore is hardly separated from the areola series in the central area. In most Gomphonema taxa, the internal opening is usually a slit-like, elongated opening, positioned between the internal proximal raphe endings (see for instance G. acuminatum in Reichardt 1999, plate 55, Fig. 4) or located at the end of a (shortened) series of areolae (G. angustatum in Reichardt 1999, plate 23, Figs 15-16) but then the opening can always be distinguished as an elongated, thin slit contrary to the short slit in G. svalbardense.

\section{Acknowledgements}

The project was supported by the Czech Ministry of Education (MSMT) via grant LM2010009. The polar ecology course was organized with the support from project nr. CZ.1.07/2.2.00/28.0190. The project was funded by the European social fund and from the government budget of the Czech Republic. Part of the research was funded within the Belspo CCAMBIO project allowing a visit to the SEM facilities of the National History Museum in London, UK. Dr. Alex Ball and the staff of the IAC laboratory at the Natural History Museum are thanked for their help with the scanning electron microscopy. Mrs. Myriam de Haan is thanked for her help with additional SEM observations at the Botanic Garden Meise, Belgium.

\section{References}

Aboal, M., Alvarez-Cobelas, M., Cambra, J. \& Ector, L. (2003) Floristic list of non marine diatoms (Bacillariophyceae) of Iberian Peninsula, Balearic Islands, and Canary Islands. Updated taxonomy and bibliography. Diatom Monographs 4: $1-639$.

Agardh, C.A. (1831) Conspectus Criticus Diatomacearum. Part 3. Lundae. Litteris Berlingianis: 33-48.

Antoniades, D., Hamilton, P.B, Douglas, M.S.V. \& Smol, J.P. (2008) Diatoms of North America. The freshwater floras of Prince Patrick, Ellef Ringnes and northern Ellesmere Islands from the Canadian Arctic Archipelago. Iconographia Diatomologica 17: 1-649. Beyens, L. (1989) Moss Dwelling Diatom Assemblages from Edgeøya (Svalbard). Polar Biology 9: 423-430.

Brébisson, A. (1838) Considérations sur les Diatomées et essai d'une classification des genres et des espèces appartenant à cette famille. Brée l'Ainé Imprimeur-Libraire, Falaise, 22 pp. http://dx.doi.org/10.5962/bhl.title.64353

Cleve, P.T. (1894) Synopsis of the Naviculoid Diatoms, Part I. Kongliga Svenska-Vetenskaps Akademiens Handlingar 26:1-194.

Cleve-Euler, A. (1895) On recent freshwater Diatoms from Lule Lappmark in Sweden. Bihang till Kongliga Svenska Vetenskaps-Akademiens Handlingar 21: 1-44.

Cleve-Euler, A. (1934) The Diatoms of Finnish Lapland. Societas Scientiarum Fennica. Commentationes Biologicae 4: 1-154.

Cleve-Euler, A. (1955) Die Diatomeen von Schweden und Finnland. Kungliga Svenska Vetenskapsakadie Handlingar 5/4: $1-232$.

Dallmann, W.K., Dypvik, H., Gjelberg, J.G., Harland, W.B., Johannessen, E.P., Keilen, H.B., Larssen, G.B., Lønøy, A., Midbøe, P.S., Mørk, A., Nagy, J., Nilsson, I., Nøttvedt, A., Olaussen, S., Pèelina, T.M., Steel, R.J. \& Worsley, D. (1999) Lithostratigraphic Lexicon of Svalbard. Norsk Polarinstitutt, Oslo.

Ehrenberg, C.G. (1832) Über die Entwicklung und Lebensdauer der Infusionsthiere; nebst ferneren Beiträgen zu einer Vergleichung ihrer organischen Systeme. Abhandlungen der Königlichen Akademie der Wissenschaften zu Berlin 1831: $1-154$.

Foged, N. (1964) Freshwater Diatoms from Spitsbergen. Tromsö Museums Skrifter, Universitetsførlaget 11: 1-204.

Foged, N. (1981) Diatoms in Alaska. Bibliotheca Phycologica 53: 1-317.

Guilizzoni, P., Marchetto, A., Lami, A., Brauer, A., Vigliotti, L., Musazzi, S., Langone, L., Manca, M., Lucchini, F., Calanchi, N., Dinelli, E. \& Mordenti, A. (2006) Records of environmental and climatic changes during the late Holocene from Svalbard: palaeolimnology of Kongressvatnet. Journal of Paleolimnology 36: 325-351. http://dx.doi.org/10.1007/s10933-006-9002-0

Greville, R.K. (1823) Scottish Cryptogamic Flora, or coloured figures and descriptions of cryptogamic plants, belonging 
chiefly to order Fungi. Edinburgh and London.

Grunow, A. (1862) Die österreichischen Diatomaceen nebst Anschluss einiger neuen Arten von andern Lokalitäten und einer kritischen Uebersicht der bisher bekannten Gattungen und Arten. Erste Folge. Epithemieae, Meridioneae, Diatomeae, Entopyleae, Surirelleae, Amphipleureae. Zweite Folge. Familie Nitzschieae. Verhandlungen der Kaiserlich-Königlichen Zoologisch-Botanischen Gesellschaft in Wien 12: 315-472, 545-588.

http://dx.doi.org/10.5962/bhl.title.64361

Hustedt, F. (1937) Sußwasserdiatomeen von Island, Spitzbergen und den Färöer-Inseln. Botanisches Archiv 38: $152-207$.

Hustedt, F. (1942) Diatomeen aus der Umgebung von Abisko in Schwedisch-Lappland. Archiv für Hydrobiologie 39: 87-174.

Komárek, J., Kováčik, L., Elster, J. \& Komárek, O. (2012) Cyanobacterial diversity of Petuniabukta, Billefjorden, central Spitsbergen. Polish Polar Research 33: 347-368. http://dx.doi.org/10.2478/v10183-012-0024-1

Krammer, K. \& Lange-Bertalot, H. (1986-1991) Bacillariophyceae . In: Ettl, H., J. Gerloff, H. Heynig \& D. Mollenhauer (eds), Süßwasserflora von Mitteleuropa, Band 2/1-2/4. Gustav Fischer Verlag, Stuttgart - New York.

Krasske, G. (1938) Beiträge zur Kenntnis der Diatomeen-Vegetation von Island und Spitzbergen. Archiv für Hydrobiologie 33: 503-553.

Kützing, F.T. (1833) Synopsis Diatomacearum oder Versuch einer systematischen Zusammenstellung der Diatomeen. Linnaea 8: 529-620. http://dx.doi.org/10.5962/bhl.title.65634

Kützing, F.T. (1844) Die Kieselschaligen Bacillarien oder Diatomeen. Nordhausen. 152 pp. http://dx.doi.org/10.5962/bhl.title.64360

Kützing, F.T. (1849) Species Algarum. Lipsiae. F.A. Brockhaus. 922 pp. http://dx.doi.org/10.5962/bhl.title.60464

Lange-Bertalot, H. \& Genkal, S.I. (1999) Diatoms from Siberia I - Islands in the Arctic Ocean (Yugorsky-Shar Strait). Iconographia Diatomologica 6: 1-303.

Láska, K., Witoszová, D. \& Prošek, P. (2012) Weather patterns of the coastal zone of Petuniabukta, central Spitsbergen in the period 2008-2010. Polish Polar Research 33: 297-318. http://dx.doi.org/10.2478/v10183-012-0025-0

Luoto, T.P., Nevalainen, L., Kubischta, F., Kultti, S., Knudsen, K.L. \& Salonen, V.-P. (2011) Late Quaternary Ecological Turnover in High Arctic Lake Einstaken, Nordaustlandet, Svalbard $\left(80^{\circ} \mathrm{N}\right)$. Geografiska Annaler: Series A, Physical Geography 93: 337-354.

http://dx.doi.org/10.1111/j.1468-0459.2011.00435.x

Mann, D.G. (1999) The species concept in diatoms. Phycologia 38: 437-495. http://dx.doi.org/10.2216/i0031-8884-38-6-437.1

Medlin, L.K. \& Kaczmarska, I. (2004) Evolution of the diatoms: V. Morphological and cytological support for the major clades and a taxonomic revision. Phycologia 43: 245-270.

Metzeltin, D. \& Witkowski, A. (1996) Diatomeen der Bären-Insel. Süsswasser- und marine Arten. Iconographia Diatomologica 4: 3-217.

Picińska-Faltynowicz, J. (1988) Freshwater benthic diatoms from the south-western part of the Horsnund fiord area, SW Spitsbergen. Polar Research 6: 19-34. http://dx.doi.org/10.3402/polar.v6i1.6843

Prach, K. \& Rachlewicz, G. (2012) Succession of vascular plants in front of retreating glaciers in central Spitsbergen. Polish Polar Research 33: 319-328. http://dx.doi.org/10.2478/v10183-012-0022-3

Rabenhorst, L. (1864) Flora Europaea Algarum aquae dulcis et submarinae. Sectio I. Algas diatomaceas complectens, cum figuris generum omnium xylographice impressis. Apud Eduardum Kummerum, Lipsiae. 359 pp. http://dx.doi.org/10.1002/ardp.186617501108

Rachlewicz, G., Szczuciński, W. \& Ewertowski, M. (2007) Post-"Little Ice Age" retreat rates of glaciers around Billefjorden in central Spitsbergen, Svalbard. Polish Polar Research 28: 159-186.

Reichardt, E. (1991) Taxonomische Revision des Artenkomplexes um Gomphonema angustum - G. dichotomum - G. intricatum - G. vibrio und ähnliche Taxa (Bacillariophyceae). Nova Hedwigia 53: 519-544.

Reichardt, E. (1999) Zur Revision der Gattung Gomphonema. Die Arten um G. affine/insigne, G. angustatum/micropus, G. acuminatum sowie gomphonemoide Diatomeen aus dem Oberoligozan in Bohmen. Iconographia Diatomologica 8:1-203.

Reichardt, E. (2001) Revision der Arten um Gomphonema truncatum und G. capitatum. In: Jahn, R., Kociolek, J.P., Witkowski, A. \& Compère, P. (eds.) Lange-Bertalot-Festschrift: Studies on Diatoms. Dedicated to Prof. Dr. Dr. h.c. Horst LangeBertalot on the occassion of his 65th Birthday. A.R.G. Gantner Verlag. K.G. pp. 187-224.

Ross, R., Cox, E.J., Karayeva, N.I., Mann, D.G., Paddock, T.B.B., Simonsen, R. \& Sims, P.A. (1979) An amended terminology for the siliceous components of the diatom cell. Nova Hedwigia Beihefte 64: 513-533.

Round, F.E., Crawford, R.M. \& Mann, D.G. (1990) The diatoms. Biology and morphology of the genera. Cambridge University Press, Cambridge, 747 pp.

Szczuciński, W. \& Rachlewicz, G. (2007) Geological setting of the Petuniabukta Region. Landform Analysis 5: $212-215$.

Thomas, E.W., Kociolek, J.P., Lowe, R.L. \& Johansen, J.R. (2009) Taxonomy, ultrastructure and distribution of gomphonemoid 
diatoms (Bacillariophyceae) from Great Smoky Mountains National Park (U.S.A.). In: Kociolek, J.P., Theriot, E.C. \& Stevenson, R.J. (eds), Diatom taxonomy, ultrastructure and ecology: modern methods and timeless questions. A tribute to Eugene F. Stoermer. Nova Hedwigia, Beiheft 135: 201-237.

Tyler, P.A. (1996) Endemism in freshwater algae. Hydrobiologia 336: 127-135. http://dx.doi.org/10.1007/bf00010826

Van de Vijver, B., Ledeganck, P., Potters, G. \& Beyens, L. (1999) Diatom communities from alkaline environments of the Brøgger peninsula, north-west Spitsbergen. Nova Hedwigia 68: 93-115.

Van de Vijver, B., Beyens, L. \& Lange-Bertalot, H. (2004) The Genus Stauroneis in the Arctic and (Sub-)Antarctic Regions. Bibliotheca Diatomologica 51: 1-317.

Van der Werff, A. (1955) A new method for cleaning and concentrating diatoms and other organisms. Verhandlungen der Internationalen Vereinigung für theoretische und angewandte Limnologie 12: 276-277.

Van Heurck, H. (1881) Synopsis des Diatomées de Belgique. Atlas. Ducaju \& Cie., Anvers. pls 31-77. http://dx.doi.org/10.5962/bhl.title.1990

Williams, D.M. \& Round, F.E. (1987) Revision of the genus Fragilaria. Diatom Research 2: 267-288. http://dx.doi.org/10.1080/0269249x.1987.9705004 